\title{
The Metaphor of War in Political Discourse on COVID-19 in Uganda
}

\author{
Dorothy Atuhura * \\ Department of Literature and Film Studies, Kyambogo University, Kampala, Uganda
}

The article examines the use of the metaphor of war in political communication on the novel COVID-19 pandemic in Uganda using two analytical tools of the social representation theory, anchoring and objectification. Drawing data for analysis from six widely televised presidential addresses to the nation on COVID-19 made by Uganda's president, H.E. Yoweri Kaguta Museveni during the months of March 2020 to September 2020, the article argues that during the time of the COVID-19 pandemic, there was a persistent dominant use of the metaphor of war by government representatives as a rhetorical device to communicate about and to make intelligible an emerging unknown virus as a threat that should be managed through combat behavior. In so doing, the use of the war metaphor and its implied call for combat behavior to control, manage, and eradicate the virus spread engendered consequences such as standardizing hegemonic understanding of the nature and causes of the virus as well as normalizing and legitimizing interventions that the

OPEN ACCESS

Edited by:

Eunice Castro Seixas,

University of Lisbon, Portugal

Reviewed by

Roopa Dhatt,

Women in Global Health,

United States

Eemeli Hakoköngäs,

University of Eastern Finland, Finland

*Correspondence:

Dorothy Atuhura

dorothy.atuhura@gmail.com

Specialty section: This article was submitted to

Disaster Communications,

a section of the journal

Frontiers in Communication

Received: 23 July 2021

Accepted: 30 December 2021

Published: 01 February 2022

Citation:

Atuhura D (2022) The Metaphor of War in Political Discourse on COVID-19

in Uganda.

Front. Commun. 6:746007. doi: 10.3389/fcomm.2021.746007 government adopted to manage it.

Keywords: Uganda (sub Saharan Africa), COVID-19, war metaphor, anchoring, objectification

\section{INTRODUCTION}

Coronavirus disease (COVID-19) was first globally identified in December 2019. In January 2020, the World Health Organization (WHO) declared it "a public health emergency of international concern" (World Health Organization, 2020). Corona virus is an infectious disease that spreads from person to person through surfaces or when an infected person speaks, coughs or sneezes and the air and/or droplets enter another person through the mouth, nose or eyes.

The first case of COVID-19 in Uganda was reported on 21st March 2020. The President of Uganda, Yoweri Kaguta Museveni, made his first national address to the nation on COVID-19 on March 18, 2020, 3 days before the first case of COVID-19 was reported in the country. The President "declared war on the virus" which at that time was seen more of a problem of the West, thus tilting and/or suspending temporarily the focus from Africa as the proverbial Other 'dark continent'. In the month of March, the President ordered several COVID-19 containment measures and these include: closure of international airport; closed ground crossing points for passengers with the exception of cargo drivers; closed schools and other high congregation points; froze public and private transport; outlawed all mass gathering events, including for worship; ordered an overnight curfew from 7:00 pm to 6:30 am; declared a total nationwide lockdown; ordered the closure of shopping malls, ordered women who sell in the food-markets to sleep at the markets and not return home for 14 days, and movement out of home was by permit only.

From March 2020, going forward, there was a collective national mood of universal siege and tension in the country. There was heightened collective feeling of dread among the public that was reminiscent of the civil wars and political insurgencies of the 70, 80, and the 90s Kony's rebel insurgency in Northern Uganda (Hayden 2020). The pervasive public feeling was of a country 
bracing itself to face an external enemy camped at its frontiers. This was partly due to the excessive use of unnecessary and in some instances lethal force by the Uganda police and the military to enforce COVID-19 containment measures. While in and of themselves, these measures were not harmful to the population, their enforcement edged on infringement and violation of "ethical and human rights principles" (Barugahare et al., 2020). In some instances, enforcement of these measures led to extra-judicial killings and injuries as is, for example, reported in a 2021 report by Amnesty International that "in Uganda, security forces killed at least 12 people, including an 80-year old woman" (Amnesty International Ltd 2021, 20). Enforcement was heavily militarized. This militarization was secured through the formation of the Inter-agency Security Joint Task Force (IAJTF) which was formed to supplement efforts of the Ministry of Health in enforcing public compliance to COVID-19 standard operating procedures, man curfew road blocks and quarantine centers all over the country that housed COVID-19 patients and hunt down suspicious COVID-19 patients, diffuse COVID-19 induced crime and combating the spread of COVID-19. The IAJTF operations were spearheaded by military officers (such as the Chief of Staff Land Forces and the UPDF's Deputy Chief of Defense Forces) from Uganda People's Defense Forces (UPDF) and was composed of officers from the Uganda Prisons Services, UPDF, Uganda Police, National Joint Intelligence Committee, officers from the Ministry of Internal Affairs such as Immigrations directorate, and Resident District Commissioners who oversee security matters at the district level.

Despite the heavy handed militarization in managing the pandemic, some public health scholars (such as Kitara and Ikoona 2020) argue that Uganda has been successful at handling the COVID-19 public health emergency because of the country's historical experience in managing similar pandemics such as HIV AIDS, Ebola, Measles, Marburg, and Hepatitis B. More so, they argue that this success is a result of the management and control measures government adopted such as "the near complete lockdown through shutting down air, road, water travels and congregate settings as well as restrictions of people's movement through the stay home policy", "an established and clear leadership structure, experienced health workforce, good political will, enabling environment, and good epidemic response by the population" (Kitara and Ikoona 2020, 1). However, such an analysis forecloses the effects engendered by those control measures as indeed, researchers working within a human rights framework have problematized them arguing that they violated human rights standards and ethics. For example, James Nkuubi in his study on how guns govern public health in Uganda asserts that increased militarization of the COVID-19 public health emergency led to a "digression of democratic values, the rule of law and human rights" (Nkuubi 2020, 638). Further, those measures violated the ethics and human rights principles in that they were very restrictive and not necessarily proportionate to the magnitude of the threat nor strictly necessary, effective, reasonable, and equitable (Barugahare et al., 2020).

While there has been commendable scholarship oriented to the study of the intersection between COVID-19, public health and human rights, there remains a dearth of scholarship on the communicative tactics deployed by political powers to make the novel COVID-19 intelligible to a Ugandan public and how these tactics eventually contributed to shaping national level strategies for managing it. In response to this gap, this article seeks to examine the social political tactics deployed through political communication to generate collectively shared local meanings and understanding of the COVID-19 health emergency and to mobilize common sense strategies to combat it. In particular, the article explores the use of the metaphor of war in six of president Museveni's addresses to the nation on COVID-19 in the months of March through September 2021. President Museveni, who has led Uganda for over 30 years, came to power through a protracted guerrilla bush war in 1986. In February 1981, the National Resistance Army under the leadership of President Museveni started a protracted guerilla bush war which after 6 years ousted Uganda's president Milton Obote in 1986. President Obote was Uganda's first Prime Minister right after Uganda's independence from British colonial rule in 1962 and later became President from 1966 up until 1971 when he was overthrown by the commander of the Ugandan Army, Idi Amin. President Obote later overthrew Idi Amin in 1980 and was re-instated as president for the second time but was then overthrown by a guerilla war led by President Museveni in 1986. As president Museveni is wont to do whenever he speaks to the public about a national or personal challenge, he gravitates to what can be described as his "comfort zone". This is what he sees as the glorious years in the bush that culminated in his triumphant capture of state power. It is no surprise therefore that in his presidential addresses to the nation on COVID-19, there is a dominant military strategy motif in his speeches in general and more specifically those on the subject of COVID-19. The diction and metaphors in the speeches are reminiscent of a battle plan delivered by a military commander. It is not unreasonable to say that the speeches themselves are metaphors of battlefield situations. Structured in a step-by-step series of actions the government and the citizens must take if they are to, in his words, "defeat" the "enemy". Each of the six speeches analyzed bears by nature both overt and subtle traces of militaristic special weapons and tactics (SWAT) as well as strategies aimed at anticipating, recognizing, investigating and neutralizing (ARIN) the enemy virus. This article therefore seeks to examine the deployment of two metaphorical mechanisms (i.e., anchoring and objectification) in president Museveni's speeches on COVID-19 and their role in making a novel pandemic intelligible to a Ugandan audience. The article begins with a reflection on the literature on metaphors and two analytical tools of the social representation theory objectification and anchoring. The article then proceeds by presenting the methodology used to collect and analyze the data drawn from Uganda's President's national addresses to the nation on COVID19 and then proceeds to discuss the findings pointing out the implications of a metaphorical framing of the pandemic in Uganda.

\section{ANCHORING AND OBJECTIFICATION}

In seeking to explore the communicative tactics deployed by political authority to make the novel COVID-19 intelligible to a 
Ugandan public, this article draws on two analytical tools of the social representation theory (i.e. objectification and anchoring) (Ribeiro et al., 2018; Höijer 2011; Moscovici 1988). In doing so, the article seeks to contribute to a body of scholarship on social representations of infectious diseases that has sought to illustrate that when social groups are faced with novel health emergencies, they cope through anchoring and objectifying them in order to explain and understand them better (e.g., Eicher and Bangerter 2015 on infectious diseases; Ngobi 2015 and; Joffe 1995 on HIV AIDS). Proposed by Moscovici (1973), the theory of social representations has been widely applied in scholarship on psychosocial concerns such as infectious diseases most particularly to examine the metaphorical uses of objectification and anchoring in social communication as well as how they enable publics to cope with and to cue collective meaning and understanding of novel infectious diseases (Moscovici 1973; Sontag, 1978; Bauer and George 1999; Wagner et al., 1999; Reisfield and Wilson 2004; Wallis and Nerlich 2005; Nie et al., 2016). It is concerned with how social groups explain, think about, know and understand novel health emergencies. It addresses the construction of everyday common-sense knowledge and understanding of unfamiliar risky emergent phenomenon and how they are communicated and made known (Höijer 2011, 3).

Social representations "make something unfamiliar, or unfamiliarity itself, familiar” (Moscovici 1984, 24; Höijer 2011, 7) by instituting a structure to which individuals orientate themselves and by which they master their material and social world (Moscovici 1973, xiii; Höijer 2011, 5). They provide a standard for comparing phenomenon and a criterion for judging the familiar with the unfamiliar, for example, past models can be used to comprehend the present (Moscovici 1981). Social representations help to explain and make sense of inexplicable incomprehensible phenomenon that individuals and social groups have insufficient knowledge or information about. They enable social groups and individuals communicate with each other intelligibly on a subject that is significantly urgent, important and (un) familiar by means of "providing them with a code for social exchange and a code for naming and classifying unambiguously the various aspects of their world and their individual group history" (Moscovici 1973, xiii; Höijer 2011, 5). Several scholars (such as Wagner et al., 1999, 97; Eicher and Bangerter 2015), have illustrated that when social groups are first faced with unfamiliar health emergencies that may threaten their social identity and threaten to disrupt their course of life, just like COVID-19 has done, they cope with the uncertainties by naming them and attributing to them characteristics which allow those uncertainties to be communicated and talked about in collectively intelligible and known terms. Serge Moscovici suggests two mechanisms of representing and making known the unfamiliar i.e., objectification and anchoring (Moscovici 1984; Wagner et al., 1999).

Objectification is "the process whereby unfamiliar and abstract objects are transformed into concrete and 'objective' commonsense realities-most notably through the use of metaphor" (Ribeiro et al., 2018, 138). Objectification is the materialization of abstract ideas into well-known concrete reality (Höijer 2011).
While anchoring is the process by which new ideas or phenomenon are related to, attached to and/or linked to a well-known phenomenon or context to make them more intelligible (Höijer 2011, 7; Ribeiro et al., 2018, 138). Anchoring can be done through naming (i.e., giving the foreign or unknown phenomenon a more well-known face, a new dimension and qualities); through metaphors i.e., understanding one unfamiliar thing in terms of the other (Höijer 2011). Metaphors anchor by relocating meaning across concepts, by giving "something a name that belongs to something else", most times on "grounds of analogy" since they are "constituted on the basis of our ability to see the similarity in dissimilars" (Nie et al., 2016, 5; see also Richards 1929, 221).

Metaphors "play a central role in the construction of social and political reality" as they govern not only our thoughts and actions, they also oversee and (over) determine our everyday functioning (Lakoff and Johnson 1980, 159). Lakoff and Johnson argue that "the essence of metaphor is understanding and experiencing one kind of thing in terms of another", and that understanding truth involves a cross-domain correlation and correspondence in which one thing is understood and experienced in terms of another different thing (Lakoff and Johnson 1980, 5). Metaphors configure and/or control our understanding of the world around us. It is thus important to investigate the meaning and effects achieved when in his presidential addresses, president Y. K. Museveni uses the metaphor of war to explain and communicate about COVID-19.

Several scholars have examined the use of metaphors, particularly the use of the war metaphor, in the media to speak about novel health emergencies such as Ebola, SARS (Wallis and Nerlich 2005), HIV AIDS (Nie et al., 2016), Cancer (Potts and Elena 2019; Harrington 2012; Reisfield and Wilson 2004; Sontag, 1978). Political authorities usually draw on metaphors and ordinary day images to speak about and make known emerging novel public health concerns (Neshkovska and Trajkova 2020; Castro Seixas, 2020). They do this through making associations between novel pandemics and what the public collectively, culturally, affectively, and politically understands and agrees upon as common knowldege. Metaphors draw on shared cultural experiences to give meaning to ideas. In her study on media response to the HIV public health crisis, Susan Sontag (1978) argues that metaphors mediate understanding and response to public health calamities by linking them to what is already collectively known. They enable the mapping of "aspects of more familiar knowledge (the so-called source domain) onto more unfamiliar knowledge (the so-called target domain)" (Lakoff and Johnson 1980; Ribeiro et al., 2018, 138). This article draws on such scholarship to explore the construction and production of collective understanding of COVID-19 in Uganda.

Several scholars have however dismissed the use of war metaphors in discourse on disease arguing that their "metaphoric currency is now dead" (Gwyn, 2001:138; see also Montgomery, 1991 and Sontag, 1978). They argue that war or militaristic metaphors imply violence, and so, it is ironic to wage war on disease when the goal is to save lives, wars do not save lives (Nie et al., 2016). Sontag (1978) argues that among sufferers, 
militaristic metaphors promote shame and guilt as it suggests that what the victims suffer is "unqualifiedly and unredeemably wicked" and that what they suffer "encourages fatalism and justifies 'severe' measures" (1978, 83 and 84). More so, the use of militaristic metaphors "concentrates on the physical, sees control as central, and encourages the expenditure of massive resources to achieve dominance" (Annas, 1995: 746). Such metaphorical uses make it easier to "sacrifice people and their rights" (Ross, 1988: 18). Reisfield and Wilson also assert that the use of the war metaphor is "inherently masculine, power-based, paternalistic and violent" (Reisfield and Wilson 2004, 4025). However, despite the dismissal, public health experts and authorities in power continue to draw on metaphors to conceptualize and to communicate about diseases because war metaphors continue to serve such functions as "preparing the population for hard times", "persuading the citizens to change their behavior, ensuring their acceptance of extraordinary rules, sacrifices; boosting national sentiments and resilience, and also in constructing enemies and shifting responsibility" (Castro Seixas 2020, 2).

\section{METHODS}

The article seeks to respond to the question of how the novel corona virus is defined, characterized, explained and made known to the Ugandan public. In more specific terms, the article investigates how the metaphor of war is deployed in president Museveni's national addresses to the nation on COVID-19 to make the novel disease intelligible to a Ugandan audience. Using qualitative methods of data collection and analysis, data analyzed for this article was got from six presidential addresses to the nation on COVID-19 made by Uganda's president, H.E. Yoweri Kaguta Museveni during the months of March 2020 to September 2020. All the six national addresses under the special theme of "COVID-19" were delivered on 18th March, 14th April, 4th May, 18th May, 3rd June and September 20, 2020. The subtitle of the March 2020 speech specifically focused on "guidelines on the preventive measure; while the May, June and September 2020 speeches were subtitled "updates on matters regarding Corona Virus". These speeches were given from time to time to make known and to up-date the country about progress of COVID-19 spread, and to explain the interventions taken or to be taken to combat spread. These national addresses worked as a top-down blueprint for national guidance on how to deal with the pandemic. Government authorities and scientists would follow up on instructions given by the president to further guide the nation on how to deal with COVID-19. This particular period is also selected because it was a time when most of the global community had put in place stringent measures to manage the seemingly out of control pandemic. The six speeches were also particularly selected on the basis of their extended use of the metaphor of war-they are linked together because of a common reference to the tactics of survival employed by Ugandans during the 1986 guerilla war that brought Museveni to Uganda's presidency. In these six speeches, the President's use of the metaphor of war was at its peak compared to the other speeches he made on COVID-19.

The researcher listened to live television broadcast of the speeches delivered by the President in-person. The full transcripts of the speeches were later accessed from the Uganda Media Center website where they are archived. The researcher later repeatedly listened to them on the YouTube channel of the national television, UBC, while comparing them with the full digital print copies accessed on the Uganda Media Center website in order to get more familiar with their content. The speeches were later coded in relation to the different manifestations of metaphoricity in the presidential addresses. Anchoring and objectification were used as analytical tools. To identify instances of anchoring and objectification, the study examined the names given to the virus and the agents involved in naming, characteristics used to explain it, the historical events and experiences compared to make it intelligible, and the metaphors deployed to make the virus comprehensible and to compare the unknown virus to already known phenomenon.

\section{FINDINGS}

Analysis of the findings shows that the metaphor of war forms an organizing theme that ties together interventions that the government of Uganda put in place to manage the spread of COVID-19 in Uganda. Drawing on illustrations showing the way two metaphorical tools, anchoring and objectification, were deployed to communicate about the emerging novel infectious disease, the analysis reveals that references to an already known guerilla war facilitated: naming COVID-19 in familiar war terms to make it intelligible; prescribing combat behavior the public should enact to mitigate spread of the disease; anchoring the disease to historical and familiar battles against other diseases and epidemics.

\section{Anchoring by Naming}

According to Serge Moscovici, naming an unknown, unfamiliar phenomenon "extricates it from a disturbing anonymity to endow it with a genealogy and to include it in a complex of specific words, to locate it, in fact, in the identity matrix of our culture" (Moscovici 2000, 46; Höijer 2011). Naming liberates the unknown from the realm of unintelligibility and anonymity and instead situates it within well-known cultural frames of reference. One of the ways the president in his national addresses makes the novel virus known to the Ugandan public is through naming it. In naming COVID-19, the president assigns it familiar characteristics, qualities and values. He re-brands the unknown virus by assigning it a recognizable brand name and in so doing makes it comprehensible by absorbing the meaning and properties of the known into the unknown. The president calls COVID-19 an "enemy", a "new virus", "a killer and disabler", a "danger", "a danger point" and an "invisible" form. In other instances, he presents this 'enemy' as a foreign intruder using journey and spatial motifs. In his speeches the president claims that the virus is not Ugandan but rather a foreign enemy that has 
travel abilities and therefore threatening to intrude on a peaceful country. The virus is framed as inherently foreign and Western (there is a dominant reference to the US and United Kingdom) and this, temporarily, stands in stark opposition to the longstanding representation of Africa as a dark continent from which viruses such as Ebola and HIV AIDS emerged. For example, in his March 18, 2020 speech he cautions the public "do everything possible to ensure that this enemy does not come here", and as a strategy, "we should move early to avoid a stampede". In his 4th May 2020 speech, he states that "in listening we confirmed what we already suspected that the danger, the polluting factors were coming from Dubai, United Kingdom, United States, China, etc., either directly into Uganda and, or in a minority of cases, through the neighboring countries" This serves to caution the public to prepare well so the 'enemy' does not reach the country's frontier. It also incites fear and has the persuasive effect of motivating the public towards combat behavior and accepting any interventions that may be put in place to stop the enemy virus from advancing into the country.

The use of motion motifs such as "does not come here" and "stampede" create the illusion of us and the illegal alien Other. The Other is constructed as foreign, alien, dangerous, and therefore the nation must be protected from it. The virus and its human vectors are inadvertently objectified as the enemy and its means of transport (the humans from other countries) respectively. Framing the virus in spatial and travel terms legitimizes aggressive militaristic interventions that were targeted at keeping the virus outside of the country's borders. Consequently, this political stance had the effect of legitimizing and normalizing aggressive crackdown on cross-border transit for both nationals and non-nationals of Uganda, mandatory quarantine for nationals returning from abroad; intolerance to and criminalization of ordinary day ways of life of the citizens which in the government eye are seen as dangerous and potential risk causes of the virus. Framing the virus as an alien was also a successful strategy for stirring up stigma against those who were travelling from abroad. The president actually advises Ugandan nationals abroad who wish to return back home to "sit out the storm", that is, if they want to avoid the inconvenience or cost of the mandatory quarantine they should stay in the "country of their temporary abode" until the "storm" passes. The phrase "sit out the storm" creates the image of a war situation where people need to take cover as in a bunker.

The virus is defined and objectified as fire. In his very first national address, the president advises that "we must do everything possible to ensure that this enemy does not come here, does not find plenty of dry grass piled up and ready for flaming. What is the dry grass that can help to start and sustain fire of a corona-virus epidemic? It is the big masses of people, gathered together and in close proximity" (Museveni, 2020). War is associated with fire and this strikes parallels with president Museveni guerilla war fought in the bush to bring him to power in 1986. Implicit in reference to the pile of dry grass is a recognition of the anticipated threat as lethal. The virus is defined in terms of a fire that can exert lethal effects on the population which he refers to as a "pile of grass" or simply the source of fuel.
References to the public as "a pile of grass" inadvertently assigns the public the role of agent responsible for enabling the pandemic 'fire'. Implied in that is also that if the public provides, enables, or becomes ideal for the virus to spread, then they will fuel or enable the lethal spread of the virus. He inadvertently apportions the responsibility for the virus spread on those who will in effect be its casualties.

References to the population as a "pile of grass" capable of being set aflame are an antecedent to and also an anchor of the virus in a historical guerrilla bush war that delivered president Museveni to power in 1986. This guerilla war is commonly referred to as the "bush war" in Uganda because it was fought in the bush and is something every Ugandan is familiar with. Using imagery of a "dry grass piled up and ready for flaming" hails understanding of the virus in terms of a bush war and associations of war with fire. The flame imagery here transforms and objectifies the virus into something beyond the realm of health into a political war context. The president speaks of the virus the same way one would to describe a type of armor or bullet proof equipment that the virus "cannot go through an intact skin like some other disease". The intact skin is here presented as an armored defense equipment or bullet proof that shields one from enemy fire attack - the corona virus.

\section{Anchoring Through the War Metaphor}

Metaphors make the unknown known through comparing it with the known. In all the six speeches, president Museveni explains the meaning of COVID-19 and suggests prevention protocols by comparing the COVID-19 health emergency with historical wars that he has led as the president of Uganda, most particularly the 1981-86 guerilla war that brought him to power. Indeed, in his 4th May speech he asserts his confidence in the ability of Ugandans to observe the necessary behaviors that can safeguard the country in the time of the pandemic. He says "Ugandans can undertake any effort, they can make sacrifices to defend themselves in any and all legitimate causes. I know this because I led them in the anti-Amin war, the war of Liberation of 1981-86 and the wars against the terrorists and cattle rustlers of 1986-2007 (with the defeat of ADF rebels in Semliki Park)". Through anchoring, the common sense understanding and meaning of these wars is mapped onto the new unknown virus and in so doing, COVID-19 assumes the properties and meanings of those wars. The President hails these historical events as an unambiguous code for naming and making known the virus, for demystifying and unambiguously shaping everyday thinking of COVID-19 to Ugandans. Ugandans are well familiar with these wars thus they not only have the currency to signify severity of the unknown emerging COVID-19 health emergency, they also establish commonsense cognition of, and comparison between, war and the pandemic. Hailing these wars enables and produces a structure through which the Ugandan community can become familiar with, understand and master the pandemic. Indeed, in his national address on May 18, 2020, the president states that "our strategy in this war is to avoid the sickness and survive/war is not fought only by anger but also by wisdom". In other words, managing the pandemic is synonymous with fighting a war consequently the strategies deployed to 
manage the pandemic have their genealogy in tactics of the guerilla war. Since meaning for a health emergency is intermingled with meaning of the guerilla war, and most importantly communicated by a political head of state and consequently adopted by the public, the social representation of COVID-19 assumes a localized but hegemonic representation.

The war frame transforms a health reality into a combat reality by modifying scientific fact into a recognizable historical event of war. The ordinary Ugandan's daily experience with COVID-19 is made known and/or explainable through President Museveni's guerilla war experience and is interwoven with it in ways that 'force' the nation to see the pandemic through a political actor and his guerilla war experience. The guerilla war of 1986 is a collective public event upon which the government and its citizens have collective understanding and from which they agree on its tactics and meaning, particularly that the war delivered Ugandans from the grip of dictatorial regimes of Amin and many years of political instability. In mentioning president Amin, he inadvertently anchors and attaches COVID-19 to strong emotions of precariousness, fear and danger that were characteristic of Amin's dictatorial regime and from which president Museveni delivered Ugandans. Thus, through framing the pandemic in combat terms, a health emergency takes on and/or assumes properties and identity of a familiar historical fact-the guerilla war that brought president Museveni to power. Articulating the reality of a pandemic in war terms assimilates and transforms the strange and unfamiliar virus into the familiar, into what is already known. Thus, making it intelligible to an ordinary citizen.

The strategies suggested to manage the pandemic are prescribed using military motifs. The president says, for the country to "survive" and to "defeat COVID-19", the public "must do everything possible to ensure that the enemy does not come" into the country. The theme of survival is reminiscent of the strategies deployed during the guerilla war. The interventions suggested to salvage the impact are framed in militaristic combat terms because the virus is defined as "an enemy", a "danger", a "killer", an attacker, a storm and a raging enemy fire. It is therefore no wonder that the president declares that "a big struggle is upon us", "this is war", and "not about convenience" but "survival". Indeed, in his 4th may 2020 speech he breaks into anecdote and anchors the pandemic and the tactics of surviving it to his 1986 guerilla war. He narrates "when we were fighting the war; if the camp was attacked the first priority was to defeat the attack on the camp". This anecdote is used to enhance the image of a war situation. More so, such framing has the effect of not only structuring how the public should think about it, it also plays a role of shaping and/or configuring public behavior and experiences to be in consonant with the combat strategy that the president proposes. He proposes that once herd immunity has been reached, these people "become a type of firebreak" such that "the war against the virus seems not to be a quick decision war but a protracted one until we find a vaccine". The irony in the use of the diction "protracted" is interesting given that his successful 1986 guerilla war falls in the protracted war category. Most importantly though, the use of such language has the effect of mobilizing the public around an already known historical path of action in warding off national enemies. It also has the effect of galvanizing public support for the proposed militaristic strategies.

War is a dominant frame in all the six presidential speeches analyzed in this article. Using the metaphor of war enables contextualization and anchoring of the virus to specific geospatial and temporal contexts. For example, during his 4th May 2020 address, the president runs through the thirty-five "measures" so far undertaken by government in the fight against the virus and concludes with a launch into the most symbolic anecdotal references to the guerilla bush war that brought him to power. He narrates that "in our bush language, all these measures were aimed at 'simaama, piga magoti, nyamanzeni, and sikilizastop', translated as 'stop, kneel, keep quiet and listen' in that way you can hear clearly ekirikukaabuza (moving in the grass or bush), locate its approximate position and act". These are synonymous with military strategy aimed at anticipating, recognizing, investigating and neutralizing the enemy. The president invites the public to re-enact similar tactics and spells them out as standard operating tactics of prevention. He inadvertently constructs the public as a legal army combatant and the virus is objectified as the illegal enemy combatant. Consequently, he declares that "anybody violating any one of them (i.e. measures) will be prosecuted and may suffer imprisonment or pay a heavy fine". Whether those imprisoned would be produced before a military tribunal is not clearly stated by the president when he makes such a proclamation given that he has declared war on the virus. However, what is implied in this war frame is that whoever does not follow the prescribed behavior of keeping the 'enemy' out of the country commits a criminal offense and inadvertently becomes an enemy combatant in the "war" against COVID-19. Those who observe the prescribed combat discipline and protect the country from the pandemic are the legal authorized combatants while the virus and those who abet its spread are the enemy combatants.

In his March 20, 2020 address to the nation, president Museveni advises that as a country, "we must fine tune our strategy against this enemy". The phrases "fine tune" and "strategy" against the enemy" enhance the militaristic tone while the use of "we" and the reflexive "our" hail connotations of a collectivity. The virus acquires the tangibility of a visible battlefield enemy. As we move to his third speech, the tone becomes more assertive as he invites collective effort in managing the spread of the virus. He, for example, refers to the pandemic as "our struggle" which hails synonyms with the theme of 'resistance struggle', which was the pet theme for the 1986 guerilla war that brought him to power. And, as he concludes his 4th May address, he praises Ugandans for fighting a good fight against the pandemic and he invokes the successful bush war spirit that Ugandans exhibited during his guerilla war:

"I, therefore, congratulate the Ugandans for doing what I knew they could do. The Ugandans can undertake any effort, they can make any sacrifice to defend themselves in any and all legitimate causes. I know this because I led them in the anti-Amin war of liberation ... wars against terrorists and cattle rustlers ... The picture of the market women that have camped in the market 
without going home reminded me of when one (1) million people of the Luweero Triangle camped in the forests having run out of their homes. They stayed until the victory in 1986. Congratulations for resurrecting the Luweero Triangle spirit of sacrifice and voluntarism. When it comes to fighting the virus the NRM always fights difficult but intelligently structured wars"

The undertones of nostalgia for a militaristic past and psyche are signified here. This reinforces the ruling government's political ideology, commitment to combat strategies, and to some extent blurs the reality of a scientific fact by framing the pandemic as a war situation. References to the war may also be inadvertently alienating, potentially traumatizing and may reinscribe unequal social relations with those who were particularly negatively impacted by that guerilla war or even among those who are unequally affected by the pandemic. The war metaphor may be understood differently by those who were negatively impacted by the guerilla war or even those negatively affected by the pandemic. Therefore, metaphorically using a war experience as a model for prevention inadvertently reproduces and legitimizes particular forms of oppression and subordination. More so, whereas objectification of coronavirus in terms of images of market women sleeping in the market served to foreground the call for vigilance and individual responsibility to protect themselves from the virus. It, on the other hand, forecloses the dire material conditions the market women experienced while observing the presidential directives such as sleeping by their market stalls and being bitten by mosquitoes during the period of the lock down since there was no transport to go back and forth home and the market, the forced isolation from their homes and families, and the risk of gender based violence suffered at night in the market. However, that notwithstanding, president Museveni declares that for survival to be possible the strategies and solutions must be looked at as a "war. It is not about convenience anymore, it is survival. A big struggle is upon us", and he goes on to say that "this is doable and we shall defeat COVID-19". He urges the country to join the "struggle", to go to "war" and to "do everything possible to ensure that the enemy does not come here".

In his national addresses, the president calls on Ugandans to unite and control the spread of COVID-19 in the country. In his speech on 4th May, he calls upon Ugandans to deploy the same strategies they deployed in the "anti-Amin war of liberation" in order to prevent the spread of COVID-19. He anchors this call for public unity to Uganda's past experiences with getting rid of dictators such as Idi Amin and invites the Ugandan public to yet again put to work their patriotic spirit in fighting an invisible, intangible, foreign enemy that is proving to exert lethal force on the country. In his first speech delivered on 18th March 202, president Museveni equates the pandemic to Idi Amin's regime. Before he declares that all public gatherings are prohibited during the pandemic, he launches into an anecdote about his non-traditional wedding to his wife Janet in 1971 due to the political insecurity caused by Idi Amin's regime. He concludes that the "Corona-virus that time was the Amin regime". The suffering of people during Amin's regime is a very concrete reality to people in Uganda. Therefore, making comparisons between the Amin's regime and the pandemic tactfully reproduces panic, anxiety and fear for the pandemic as was for Idi Amin's regime. The president constructs the standard operating procedures for beating COVID-19 along the same ethic as the survival tactics Ugandans employed to survive Idi Ami's dictatorship. Consequently, equating the tactics the people of Uganda employed to survive Amin's dictatorship and the tactics required to manage and control the spread of COVID-19 in Uganda serves the function of heightening fear of the pandemic, concretizing understanding of the pandemic, and increasing the value of the president's message.

Naming patients as victims is consistent with war situation diction. In his speeches, the president frames COVID-19 patients in militaristic terms as "victims" and not simply as patients while those at risk of contracting the disease are referred to using terminology such as "concentration points", "frontline", "the real danger to society". Such diction creates the imagery and illusion of a war situation. The elderly persons are presented as the proverbial weak link in the chain of military defense when he refers to them as "the real danger to society". They are referred to as the "vulnerable" or "potential victims" in his speeches and therefore must be protected. The president uses the term "concentration points" to refer to large groups of the population concentrated in one place and that may provide an environment for the quick spread of the virus. These he identifies as schools, public transport, churches, and markets. He states that "it is wise that we remove these concentration points". The use of the terminology "concentration points" is consistent with combat strategy since they present as a target for the enemy to attack. He proposes "all these institutions without exception should close so that we deny the virus these concentration" that "it is a smart way of avoiding these concentrations in the face of this danger". To protect the vulnerable he suggests combat-like strategies using phrases such as "it is wise that we remove these concentration points", "so that we deny this virus those concentrations", and "it is a smart way of avoiding these concentrations in the face of this danger". In his first speech on 18th March he states that one of the characteristics of the virus is that "it does not kill many it infects" and its "kill ratio is not very high". He proposes a "fight against COVID-19" and goes on to suggest that asymptomatic patients may "defeat the virus" without ever knowing that they were ever sick. Instead of using phrases such as 'mortality rate' or 'deaths resulting from', the president's choice of "kill ratio" and "defeat" signifies militaristic action motifs, which objectify the virus as an enemy combatant and the patients as victims. He proposes the healthy body as a secure equipment or shield that can protect one against enemy fire. The virus is objectified as an actively malevolent enemy on a destructive mission so the public should "eat foods that strengthen our body soldiers (immune system) to fight the enemy". He advises that the virus "cannot go through an intact skin" and "on the defensive side, make it a habit never to casually touch your mouth, nose or your eyes with unwashed hands". Such statements frame the skin as a bulletproof and armor which when kept "intact" can prevent one from virus attack. 
The president takes the lead in producing hegemonic definitions of the virus and prescribing solutions using militaristic terms. In his March 18, 2020 address to the nation, president Museveni notes that "after listening to our scientists and watching commentators" the virus has "characteristics that will help us defeat it". The word "defeat" is mostly associated with combat situations, therefore using it in reference to a disease reinforces a particular political ideology and agenda. It also frames the scientists as an intelligence team responsible for informing the commander-in-chief on how to 'defeat' the "enemy" virus. In one of the national addresses, the President recognizes the presence of a male scientist whom he introduces in militaristic vocabulary as his "advisor on epidemics who is a veteran of fighting these epidemics". The scientists or rather the 'veterans of fighting' as the president calls them are constructed and framed as having greater power and authority than any other in shaping the country's understanding of the coronavirus. They are accredited by the president through his speeches as the experts with worthy legitimate intelligence and knowledge that can credibly be quoted when defining and explaining the nature of the virus. Ergo, the social representations of the virus they put across come off as hegemonic, coercive and must consensually be accepted by the public as 'gospel truth'. The coercive militaristic definitions of the virus these actors put across are thus prioritized over and above any other, something that forecloses other ways of knowing and shuts out other knowing voices.

\section{Anchoring Through Past Diseases}

The response to the coronavirus epidemic is anchored to historical and familiar battles against other diseases and epidemics. In all the speeches analyzed, the COVID-19 pandemic is articulated alongside other epidemics, diseases and prevention strategies are drawn from previous ones employed to control previous diseases. Past diseases invoked are HIV AIDS, Ebola, Marburg, Yaws, Leprosy, Smallpox. Consequently, characteristics of past diseases and epidemics are generalized to coronavirus. In his third speech, the president claims that the virus is "very easy to defeat" and goes on to invoke his earlier conquests of other diseases. He anchors the virus in already known diseases when he asserts in his March 18, 2020 speech that COVID-19 "belongs to the family of the common-cold [Senyiga, Rubyamira (loosely translated in local Uganda languages Luganda and Runyankole for common cold)], group of viruses" and that "it makes some people very sick because, being a new virus, all of us do not have immunity against it because we had never been exposed to it". The president acknowledges it is a new unknown phenomenon that has characteristics similar to already known common colds. He also makes statements like "although the kill ratio of the virus is not very high compared to, for instance, Ebola", "we shall defeat it as we did Ebola" "that is how I fought AIDS". He says that he used information from the experts (read spies/ intelligence information) to "design" the ABC (Abstinence, Be faithful, use Condoms) strategy that was very "effective" in "defeating" AIDS. Using such language has the effect of transferring some aspects and characteristics of past diseases, the way past diseases were managed, and mapping them onto coronavirus. In his fourth speech he reassures the nation that "what we are dealing with are not new things. They have been there in the past and were handled. This too will be handled". Here he alludes to his past battles and conquests in managing the spread of previous disease outbreaks. In his speech on 18th March he says "by confronting this disease with enlightened, scientifically based actions, we shall defeat it as we did Ebola three times, with Marburg and with AIDS". The word "confronting" is in keeping with the idea of facing the virus as an enemy at war. While the words "enlightened, scientifically based actions" are reeled in a tone that one would use when talking about weapons of war. The sentence "we shall defeat it as we did Ebola" is allusive of the guerilla war that he fought which he always gravitates to when he is confronted by a threat. It is like a refrain in a song.

\section{CONCLUSION}

This study found that through political communication the metaphor of war was used to make known an emerging virus to a Ugandan audience. The metaphor of war was used to mobilize the Ugandan public to cope with the pandemic. The metaphor worked as a myth by establishing the sanctity of combat behavior proposed by the president to manage the pandemic. The metaphor has its roots in the political history of the country and is a result of the historical wars that Uganda under president Museveni has experienced. The president reconstructs the events of these wars, most particularly the 1986 guerilla war, through anecdotal references, which then become the foundation for convincing the public into enacting combat behavior necessary for managing the pandemic. While the war metaphor expressed the military psyche of the ruling government, it also confirmed and provided the values, norms and pattern of behavior that the government expected its citizens to enact during the time of the pandemic.

\section{DATA AVAILABILITY STATEMENT}

The original contributions presented in the study are included in the article/Supplementary Material, further inquiries can be directed to the corresponding author.

\section{AUTHOR CONTRIBUTIONS}

The author confirms being the sole contributor of this work and has approved it for publication. 


\section{REFERENCES}

Amnesty International Ltd (2021). 'Amnesty International Report 2020/21: The State of the World's Human Rights'. London (UK), United Kingdom: Amnesty International Ltd.

Annas, G. (1995). Reframing the Debate on Health Care Reform by Replacing Our Metaphors. New England. J. Med. 332 (January), 744.

Barugahare, J., Nakwagala, F. N., Sabakaki, E. M., Ochieng, J., and K Sewankambo, N. (2020). Ethical and Human Rights Considerations in Public Health in Low and Middle-Income Countries: an Assessment Using the Case of Uganda's Responses to COVID-19 Pandemic. BMC Med. Ethics 21 (1), 91-12. doi:10.1186/s12910-020-00523-0

Bauer, M. W., and Gaskell, G. (1999). Towards a Paradigm for Research on Social Representations. J. Theor. Soc. Behav. 29 (2), 163-186. doi:10.1111/1468-5914.00096

Castro Seixas, E. (2020). War Metaphors in Political Communication Q13 on COVID-19. Front. Sociol. 5, 583680. doi:10.3389/fsoc.2020.583680

Eicher, V., and Bangerter, A. (2015). "Social Representations of Infectious Diseases," in The Cambridge Handbook of Social Representations. Editors E. Andreouli, G. Gaskell, S. Gordon, and J. Valsiner (Cambridge: Cambridge University Press).

Gwyn, R. (2001). "Communicating Health and Illness," Codes and Combat in Biomedical Discourse. Editor L. Scott (SAGE Montgomery) 2 (3), 341-390.

Harrington, K. J. (2012). The Use of Metaphor in Discourse about Cancer: A Review of the Literature. Clin. J. Oncol. Nurs. 16, 408-412. doi:10.1188/ 12.cjon.408-412

Hayden, S. (2020). Coronavirus: Ugandans Prepare for a New War as Clampdown Takes Hold. Dublin: The Irish Times.

Höijer, B. (2011). Social Representations Theory. Nordicom Rev. 32 (2), 3-16.

Joffe, H. (1995). Social Representations of AIDS: Towards Encompassing Issues of Power. Pap. Soc. Representations 4 (1), 29-40.

Kitara, D. L., and Ikoona, E. N. (2020). COVID-19 Pandemic, Uganda's Story. Pan Afr. Med. J. 35 (Suppl. 2), 23433. doi:10.11604/pamj.supp.2020.35.2.23433

Lakoff, G., and Johnson, M. (1980). Metaphors We Live by. Chicago: University Of Chicago Press.

Moscovici, S. (1973). "Foreword," in Health and Illness: A Social Psychological AnalysisClaudine Herzlich, Xiii (London, New York: Academic Press).

Moscovici, S. (1981). "On Social Representations," in Social Cognition: Perspectives On Everyday Understanding, by Joseph Forgas, 181-210 (LondonNew York: Academic Press).

Moscovici, S.(2000). Social Representations: Explorations in Social Psychology. Cambridge, UK: WileyPolity Press.

Moscovici, S. (1984). “The Phenomenon of Social Representations," in Social RepresentationsRobert Farr and Serge Moscovici (Cambridge, UK: Cambridge University Press).

Moscovici, S. (1988). Notes towards a Description of Social Representations. Eur. J. Soc. Psychol. 18 (3), 211-250. doi:10.1002/ejsp.2420180303

Museveni, Y. K. (2020). Guidelines on Covid-19 Preventive Measures. Address to the Nation on Covid-19. State House Entebbe.

Neshkovska, S., and Trajkova, Z. (2020). Coronavirus-Inspired Metaphors in Political Discourse. Thesis 9 (2), 99-132. doi:10.46763/palim2090099n
Ngobi, J. (2015). Potential Contribution of the Social Representations Theory to HIV Prevention in Uganda: Theoretical and Empirical Issues | Papers on Social Representations'. Papers On Social Representations. Soc. Psychol. Soc. Change Beyond West. Perspect. 24 (1), 21-23. doi:10.1515/nor-2017-0109

Nie, J.-B., Gilbertson, A., de Roubaix, M., Staunton, C., van Niekerk, A., Tucker, J. D., et al. (2016). Healing without Waging War: Beyond Military Metaphors in Medicine and HIV Cure Research. Am. J. Bioeth. 16 (10), 3-11. doi:10.1080/ 15265161.2016.1214305

Nkuubi, J. (2020). When Guns Govern Public Health: Examining the Implications of the Militarised COVID-19 Pandemic Response for Democratisation and Human Rights in Uganda. Afr. Hum. Rights L. J.i 20 (2), 11. doi:10.17159/19962096/2020/v20n2a11

Potts, A., and Semino, E. (2019). Cancer as a Metaphor. Metaphor and Symbol 34 (2), 81-95. doi:10.1080/10926488.2019.1611723

Reisfield, G. M., and Wilson, G. R. (2004). Use of Metaphor in the Discourse on Cancer. Jco 22 (19), 4024-4027. doi:10.1200/jco.2004.03.136

Ribeiro, B., Hartley, S., Nerlich, B., and Jaspal, R. (2018). Media Coverage of the Zika Crisis in Brazil: The Construction of a 'war' Frame that Masked Social and Gender Inequalities. Soc. Sci. Med. 200, 137-144. doi:10.1016/ j.socscimed.2018.01.023

Richards, I. A. (1929). Practical Criticism: A Study of Literary Judgment. LondonTrench, Trubner: K. Paul.

Ross, J. W. (1988). Ethics and the language of AIDS. AIDS, 39-48.

Sontag, S. (1978). Illness as Metaphor. New York, NY: Farrar, Straus and Giroux. Wagner, W., Farr, R., Jovchelovitch, S., Lorenzi-Cioldi, F., Markova, I., Gerard Duveen, et al. (1999). Theory and Method of Social Representations. Asian J. Soc. Psychol. 2 (April), 95-125. doi:10.1111/1467-839x.00028

Wallis, P., and Nerlich, B. (2005). Disease Metaphors in New Epidemics: The UK Media Framing of the 2003 SARS Epidemic. Soc. Sci. Med. 60 (11), 2629-2639. doi:10.1016/j.socscimed.2004.11.031

World Health Organization (2020). "Statement on the Second Meeting of the International Health Regulations (2005) Emergency Committee Regarding the Outbreak of Novel Coronavirus (2019-NCoV)," in Teleconference: World Health Organization.

Conflict of Interest: The author declares that the research was conducted in the absence of any commercial or financial relationships that could be construed as a potential conflict of interest.

Publisher's Note: All claims expressed in this article are solely those of the authors and do not necessarily represent those of their affiliated organizations, or those of the publisher, the editors and the reviewers. Any product that may be evaluated in this article, or claim that may be made by its manufacturer, is not guaranteed or endorsed by the publisher.

Copyright (c) 2022 Atuhura. This is an open-access article distributed under the terms of the Creative Commons Attribution License (CC BY). The use, distribution or reproduction in other forums is permitted, provided the original author(s) and the copyright owner(s) are credited and that the original publication in this journal is cited, in accordance with accepted academic practice. No use, distribution or reproduction is permitted which does not comply with these terms. 